\title{
Notes from the Editor
}

$\mathbf{T}$ his issue of the Review completes the sixth and final volume to appear with my name on the masthead. Over the last six years, our readers will have noticed and will, I hope, have admired the striking graphics adorning the cover of each issue (for which I continue to express my appreciation to Rob Hauck and Steve Yoder of the APSA office). Those who have taken the trouble to read the editorial comments that have opened every issue will also know that in each instance the cover graphic has been keyed to the theme of the "lead" article in an issue. This issue is the lone exception to that pattern-an exception born of a small bit of self-indulgence on the part of the departing editor.

The cover of "my" very first issue of the Review, in March 2002, featured a peace symbol. I chose that symbol because it appealed to me on many dimensions, not least of which was my Rodney King-like reaction to the disenchantment and strife that were then sweeping through our discipline, much of it directed toward the Review itself. Over the last six years, the Review's staff, editorial board, and I have tried to do whatever we legitimately could to advance the historic mission of the Review: publishing the very best research from the scattered precincts of our farflung discipline. We have tried both to maintain high professional standards and efficiency and transparency in the review process and to consider on their merits papers representing various approaches and subject matters.

In any event, this issue's cover graphic recycles the peace symbol from our March 2002 issue. This is not because we have finally depleted the storehouse of good ideas for a cover. Rather it is because, first, the discipline now appears to be in a more peaceful place than it was six years ago, and that progression seems worth commemorating; second, because I want to leave the Review in the same spirit as I entered it-with the best wish I can think of for it and for the discipline.

As a final self-indulgence, I am taking the liberty of using this space to express my sincere gratitude to the APSA presidents under whom I have served: to Michael Brintnall and his comrades in arms at the APSA office; to the APSA Council; to the members of the Review's editorial board; to Elizabeth Cook, the assistant editor who has worked closely with me and to the editorial assistants who have worked with us; to the thousands of authors who have entrusted their work to our review process; and to the thousands of reviewers who have willingly provided their expertise and judgment. Well done, one and all! I have been honored and privileged to serve as editor of the Review, and I can only hope that the new editorial team will find the enterprise no less rewarding and enjoyable than I have done.

\section{IN THIS ISSUE ${ }^{1}$}

In the late 1970s, the American television program Saturday Night Live regularly and often hilariously spoofed the acrimonious "Point-Counterpoint" 60 Minutes exchanges between conservative James J. Kilpatrick and liberal Shana Alexander. In these skits, Dan Akroyd would begin his remarks to Jane Curtin with the trademark phrase, "Jane, you ignorant slut," and the discussion would spiral downward from there. That combative format of televised consideration of public issues has, if anything, become much more prominent on television today than it was 3 decades ago, and what one sees and hears on these "shout shows" sometimes makes the Saturday Night Live scripts seem tame by comparison. What effect does this coarsening of political dialog have on viewers? Does it actually alter their opinions, or do they simply write these programs off as entertainment - the political equivalent of mud wrestling? These are precisely the issues that Diana C. Mutz tackles in "Effects of 'InYour-Face' Television Discourse on Perceptions of a Legitimate Opposition." Using innovative experimental techniques, Mutz captures viewers' visceral reactions to such exchanges. In a study that should be of prime interest to political psychologists and media specialists, but more broadly to anyone who relies heavily on television for understanding politics, Mutz finds that both the form and the nature of political information shape viewers' perceptions.

Dennis Chong and James N. Druckman present another ambitious analysis of political rhetoric and debate "Framing Public Opinion in Competitive Democracies," an earlier version of which was named the best paper presented at the 2006 APSA annual meeting. Chong and Druckman's experiments enable them to assess the impact of one frame in competition with another based on both its strength and its frequency. With results suggesting that the quality of framing matters more than the extensiveness of the frame, Chong and Druckman's work provides a positive outlook on democratic challenges. ${ }^{1}$

Government waste as a result of pork-barrel projects, such as the infamous "bridge to nowhere," is a staple of modern political coverage and a predictable irritant to a citizenry that considers itself overtaxed. To this point, the scholarly consensus has been that the larger the legislature, the more government is likely to spend on such projects, reflecting the need to spread the wealth among the constituencies of a large number of legislators. Yet the results of recent studies have not conformed to this notion. In "The Law of $\mathrm{k} / \mathrm{n}$ : The Effect of Chamber Size on Government Spending in

\footnotetext{
${ }^{1}$ This section was drafted by editorial assistant Elizabeth Franker.
} 
Bicameral Legislatures," Jowei Chen and Neil Malhotra resolve this discord between expectation and evidence by emphasizing the importance of one particular feature of bicameral legislatures. The number of lower house seats relative to seats in the upper house, they find, plays a key role in shaping the incentives and behavior of members of the lower house. By resolving the puzzle with which they began, Chen and Malhotra strengthen theory and provide insight into the practice of legislative politics.

The next three articles in this issue focus on ethnicity in the provision of public goods, in building state unity, and in ending wars of nationalism. In "Partition as a Solution to Wars of Nationalism: The Importance of Institutions," Thomas Chapman and Philip G. Roeder identify key causal mechanisms that explain different outcomes, reaching conclusions that defy the prevailing anti-partition wisdom. Chapman and Roeder's analysis should be considered a must-read for both scholars and policymakers concerned with civil war resolution, as its focus on the impact of institutions on outcomes such as peace duration and democratization fills a wide gap in the literature.

In "Can Institutions Build Unity in Multiethnic States?" Zachary Elkins and John Sides continue along the same general lines, this time by examining the role of institutions in resolving ethnic differences within an established multiethnic state. As in the Chapman and Roeder study, Elkins and Sides's findings call into question the conventional wisdom, which in this instance advocates federalism and proportional representation as means of grappling with the challenges engendered by ethnic differences. These solutions, it appears, simply do not live up to the hype surrounding them.

Whereas Elkins and Sides focus on the gap between majority and minority groups and their relative degrees of national identity, James Habyarimana, Macartan Humphreys, Daniel N. Posner, and Jeremy Weinstein look at the flip side of this issue. In "Why Does Ethnic Diversity Undermine Public Goods Provision?" this research team reports on a natural experiment in the slums of Kampala, Uganda, where local entities are responsible for providing public goods. Taking as their starting point the fact that less diverse areas receive better services, the authors design a series of imaginative games to identify the reasons for this observed disparity. Their finding go well beyond the standard explanations attributing cooperation to shared tastes, making this analysis a worthy contribution to the extensive literature on ethnicity.

Reflecting the diversity of our discipline, we next shift the scene to two articles by political theorists and two by comparativists. In his exploration of sociality in "Rousseau's Discriminating Defense of Compassion," Jonathan Marks improves on current scholarship on Rousseau's theme of compassion by focusing on it in relation to other elements, such as self-interest or virtues, rather than to isolation. In an exemplary display of scholarship, Marks presents his discussion of Rousseau's sophisticated political psychological defense of compassion alongside counterevidence, show- ing his readers what is at stake in the dispute and presenting them with clear alternatives.

In "'What Does Heaven Ever Say?' A Methodscentered Approach to Cross-cultural Engagement," Leigh Kathryn Jenco invites political scientists to throw off the shackles of Western political thought and embrace alternative frames of reference. The allegedly unbiased method of cross-culturalism is not enough; Jenco argues, a position she illustrates by examining whether a dialog is a viable method in cross-cultural analysis.

Etel Solingen's "Pax Asiatica versus Bella Levantina: The Foundations of War and Peace in East Asia and the Middle East" demonstrates some of the best features of historical and comparative analysis. Solingen begins by observing that whereas East Asia and the Middle East shared many attributes immediately after World War II, they exhibit vast differences today. She identifies the key to this divergence by considering models of development. Her novel theoretical account of an important question is supported by a detailed plausibility probe and supplemented by an examination of competing explanations. Scholars of both comparative politics and international relations will want to read this article for its methodological and theoretical contributions.

"Strikes and Labor Organization in Hybrid Regimes," by Graeme B. Robertson, uses new data on Russia to develop a general theory of strikes and labor organizations in partially liberalized countries. Robertson begins with the observation that because unions have different functions in hybrid regimes than in democracies, current understandings based on their operation in democracies are inadequate. By examining patterns of strikes and protest activity in Russia, he is able to provide an account of labor activity in these hybrid regimes. Because this article adds significantly to the literatures on political mobilization, labor politics, hybrid regimes, and postcommunist politics, it should appeal to a wide range of scholars.

The next three contributions in this issue contribute to both formal theory and their respective policy areas. Robert Powell's "Allocating Defensive Resources with Private Information about Vulnerability" speaks to questions of public policy and domestic security-specifically how best to secure potential terrorist targets. Whereas common sense seems to tell us that more is better, especially when security at a nuclear power plant is in question, Powell points to the dangers of inadvertently providing information to terrorists, who may see where money is being spent and adjust their strategy accordingly.

In "Institutions and Equilibrium in the United States Supreme Court," Robert Anderson IV and Alexander M. Tahk relax two primary assumptions of earlier theoretical work on the Supreme Court, unidimensionality and binary choice, to create a more accurate picture of decision making. In so doing, Anderson and Tahk also manage to provide a more solid theoretical foundation for past and future game theoretic work on the Supreme Court. 
Harry S. Truman once remarked, "Men make history, and not the other way around. In periods where there is no leadership, society stands still. Progress occurs when courageous, skillful leaders seize the opportunity to change things for the better." Thus, a key to understanding politics is understanding leadership. Torun Dewan and David P. Myatt help us do just that in "Leading the Party: Coordination, Direction, and Communication." Dewan and Myatt use formal modeling tools to analyze the extent to which leaders can coordinate mass action. This question not only has important theoretical implications but also can aid our understanding of the real, day-to-day policy world.

Our "Forum" section reopens a discussion begun in the December 1999 issue of the Review by Massimo Morelli in "Demand Competition and Policy Compromise in Legislative Bargaining." Maria Montero and Juan J. Vidal-Puga make a worthwhile reconsideration of the complexities and limitations of Morelli's model. Departing from the customary stance of critiqued authors, Morelli embraces Montero and Vidal-Puga's results, focusing on the implications of the revision of the literature on demand bargaining.

\section{INSTRUCTIONS TO CONTRIBUTORS}

The American Political Science Review (APSR) strives to publish scholarly research of exceptional merit, focusing on important issues and demonstrating the highest standards of excellence in conceptualization, exposition, methodology, and craftsmanship. Because the APSR reaches a diverse audience of scholars and practitioners, authors must demonstrate how their analysis illuminates a significant research problem or answers an important research question, of general interest in political science. For the same reason, authors must strive for a presentation that will be understandable to as many scholars as possible, consistent with the nature of their material.

The APSR publishes original work. Therefore, authors should not submit articles containing tables, figures, or substantial amounts of text that already have been published or are forthcoming in other places, or which are included in other manuscripts submitted for review to book publishers or periodicals (including online journals) or otherwise committed. In many such cases, subsequent publication of this material would violate the copyright of the other publisher. The APSR also does not consider papers that are currently under review at other journals or duplicate or overlap with parts of larger manuscripts that have been submitted to other publishers (including publishers of both books and periodicals). Submission of manuscripts substantially similar to those submitted or published elsewhere, or to part of a book or other larger work, is also strongly discouraged. If you have any questions about whether these policies apply in your particular case, you should discuss any such publications related to a submission in a cover letter to the Editors. You should also notify the Editors of any related submissions to other publishers, whether for book or periodical publication, that occur while a manuscript is under review at the APSR and which would fall within the scope of this policy. The Editors may request copies of related publications.

The APSR uses a double-blind review process. If your manuscript contains quantitative evidence and analysis, you should describe your procedures in sufficient detail to permit reviewers to understand and evaluate what has been done and, in the event the article is accepted for publication, to permit other scholars to carry out similar analyses on other data sets. For example, for surveys, at the least, sampling procedures, response rates, and question wordings should be given; you should calculate response rates according to one of the standard formulas given by the American Association for Public Opinion Research, Standard Definitions: Final Dispositions of Case Codes and Outcome Rates for Surveys (Lenexa, KS: AAPOR, 2006). This document is available on the Internet at http://www.aapor.org/standards.asp. For experiments, provide full descriptions of experimental protocols, methods of subject recruitment and selection, subject payments and debriefing procedures, and so on. Articles should be self-contained, so you should not simply refer readers to other publications for descriptions of these basic research procedures.

Please indicate variables included in statistical analyses by capitalizing the first letter in the variable name and italicizing the entire variable name the first time each is mentioned in the text. You should also use the same names for variables in text and tables, and wherever possible should avoid use of acronyms and computer abbreviations when discussing variables in the text. All variables appearing in tables should have been mentioned in the text and the reason for their inclusion discussed.

As part of the review process, you may be asked to submit additional documentation if procedures are not sufficiently clear; the review process works most efficiently if such information is given in the initial submission. If you advise readers that additional information is available, you should submit copies of that information with the manuscript as "attached materials" on our website. If the amount of this supplementary information is extensive, please inquire about alternate procedures.

Manuscripts that are largely or entirely critiques or commentaries on previously published articles will be reviewed using the same general procedures as for other manuscripts, with one exception. In addition to the usual number of reviewers, such manuscripts will also be sent to the scholar(s) whose work is being criticized, in the same anonymous form as they are sent to reviewers. Comments from the original author(s) to the editor will be invited as a supplement to the advice of reviewers. This notice to the original author(s) is intended: (1) to encourage review of the details of analyses or research procedures that might escape the notice of disinterested reviewers; (2) to enable prompt publication of critiques by supplying criticized authors with early notice of their existence and, therefore, more 
adequate time to reply; (3) as a courtesy to criticized authors.

The APSR accepts only electronic submissions. To submit a manuscript, please go to http://apsr. edmgr.com. This web site provides detailed information about the submission procedure and required manuscript formatting. Please direct any questions to the managing editor at apsr@polisci.ucla.edu.

\section{ELECTRONIC ACCESS TO THE APSR}

Back issues of the APSR are available in several electronic formats and through several vendors. Except for the last three years (as an annually "moving wall"), back issues of the APSR beginning with Volume 1, Number 1 (November 1906), are available on-line through JSTOR (http://www.jstor.org/). At present, JSTOR's complete journal collection is available only via institutional subscription, e.g., through many college and university libraries. For APSA members who do not have access to an institutional subscription to JSTOR, individual subscriptions to its APSR content are available. Please contact Member Services at APSA for further information, including annual subscription fees.

Individual members of the American Political Science Association can access recent issues of the APSR and PS through the APSA website (www.apsanet.org) with their username and password. Individual nonmember access to the online edition will also be available, but only through institutions that hold either a print-plus-electronic subscription or an electronic-only subscription, provided the institution has registered and activated its online subscription.

Full text access to current issues of both the APSR and $P S$ is also available on-line by library subscription from a number of database vendors. Currently, these include University Microfilms Inc. (UMI) (via its CDROMs General Periodicals Online and Social Science Index and the on-line database ProQuest Direct), Online Computer Library Center (OCLC) (through its on-line database First Search as well as on CDROMs and magnetic tape), and the Information Access Company (IAC) (through its products Expanded Academic Index, InfoTrac, and several on-line services [see below]). Others may be added from time to time.

The APSR is also available on databases through six online services: Datastar (Datastar), Business Library (Dow Jones), Cognito (IAC), Encarta Online Library (IAC), IAC Business (Dialog), and Newsearch (Dialog).

The editorial office of the APSR is not involved in the subscription process to either JSTOR for back issues or the other vendors for current issues. Please contact APSA, your reference librarian, or the database vendor for further information about availability.

\section{BOOK REVIEWS}

The APSR no longer contains book reviews. As of 2003, book reviews have moved to Perspectives on Politics. All books for review should be sent to the Per- spectives on Politics Book Review Editor, Jeffrey C. Isaac. The address is Professor Jeffrey C. Isaac, Review Editor, Perspectives on Politics, Department of Political Science, Woodburn Hall, 1100 E. 7th St., Indiana University, Bloomington, IN 47405-7110. E-mail: isaac@indiana.edu.

If you are the author of a book you wish to be considered for review, please ask your publisher to send a copy to the Perspectives on Politics Book Review Editors per the mailing instructions above. If you are interested in reviewing books for Perspectives on Politics, please send your vita to the Book Review Editors; you should not ask to review a specific book.

\section{OTHER CORRESPONDENCE}

The American Political Science Association's address, telephone, and fax are 1527 New Hampshire Avenue, N.W., Washington, D.C. 20036, (202) 483-2512 (voice), and (202) 483-2657 (fax). E-mail: apsa@apsanet.org. Please direct correspondence as follows.

Information, including news and notes, for PS:

$$
\begin{aligned}
& \text { Dr. Robert J-P. Hauck, Editor, PS } \\
& \text { E-mail: rhauck@apsanet.org }
\end{aligned}
$$

Circulation and subscription correspondence (domestic claims for nonreceipt of issues must be made within four months of the month of publication; overseas claims, within eight months):

\section{Sean Twombly, \\ Director of Member Services \\ E-mail: membership@apsanet.org \\ Reprint permissions: \\ E-mail: Rights@cambridge.org}

Advertising information and rates:

Advertising Coordinator,

Cambridge University Press

E-mail: journals_advertising@cambridge.org

\section{EXPEDITING REQUESTS FOR COPYING APSR AND PS ARTICLES FOR CLASS USE AND OTHER PURPOSES}

\section{Class Use}

The Comprehensive Publisher Photocopy Agreement between APSA and the Copyright Clearance Center (CCC) permits bookstores and copy centers to receive expedited clearance to copy articles from the $A P S R$ and $P S$ in compliance with the Association's policies and applicable fees. The general fee for articles is 75 cents per copy. However, current Association policy levies no fee for the first 10 copies of a printed artide, whether in course packs or on reserve. Smaller classes that rely heavily on articles (i.e., upper-level undergraduate and graduate classes) can take advantage of this provision, and faculty ordering 10 or fewer course packs should bring it to the attention of course pack 
providers. APSA policy also permits free use of the electronic library reserve, with no limit on the number of students who can access the electronic reserve. Both large and small classes that rely on these articles can take advantage of this provision. The CCC's address, telephone, and fax are 222 Rosewood Drive, Danvers, MA 01923, (978) 750-8400 (voice), and (978) 750-4474 (fax). This agreement pertains only to the reproduction and distribution of APSA materials as hard copies (e.g., photocopies, microfilm, and microfiche).

The Association of American Publishers (AAP) has created a standardized form for college faculty to submit to a copy center or bookstore to request copyrighted material for course packs. The form is available through the $\mathrm{CCC}$, which will handle copyright permissions.

APSA also has a separate agreement pertaining to CCC's Academic E-Reserve Service. This agreement allows electronic access for students and instructors of a designated class at a designated institution for a specified article or set of articles in electronic format. Access is by password for the duration of a class.

Please contact your librarian, the CCC, or the APSA Reprints Department for further information.

\section{APSR Authors}

If you are the author of an APSR article, you may use your article in course packs or other printed materials without payment of royalty fees and you may post it at personal or institutional web sites as long as the APSA copyright notice is included.

\section{Other Uses of APSA-Copyrighted Materials}

For any further copyright issues, please contact the APSA Reprints Department.

\section{INDEXING}

Articles appearing in the APSR before June 1953 were indexed in The Reader's Guide to Periodical Literature. Current issues are indexed in $A B C P o l$ Sci; America, History and Life 1954-; Book Review Index; Current Contents: Social and Behavioral Sciences; EconLit; Energy Information Abstracts; Environmental Abstracts; Historical Abstracts; Index of Economic Articles; Information Service Bulletin; International Bibliography of Book Reviews of Scholarly Literature in the Humanities and Social Sciences; International Bibliography of Periodical Literature in the Humanities and Social Sciences; International Index; International Political Science Abstracts; the Journal of Economic Literature; Periodical Abstracts; Public Affairs; Public Affairs Information Service International Recently Published Articles; Reference Sources; Social Sciences and Humanities Index; Social Sciences Index; Social Work Research and Abstracts; and Writings on American History. Some of these sources may be available in electronic form through local public or educational libraries. Microfilm of the APSR, beginning with Volume 1, and the index of the APSR through 1969 are available through University Microfilms Inc., 300 North Zeeb Road, Ann Arbor, MI 48106 (www.umi.com). The Cumulative Index to the American Political Science Review, Volumes 63 to 89: 1969-95, is available through the APSA. 